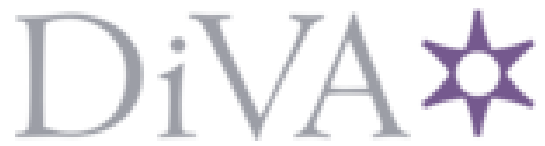

http://www.diva-portal.org

This is the published version of a paper published in Ecosystems (New York. Print).

Citation for the original published paper (version of record):

Egelkraut, D., Aronsson, K-Å., Allard, A., Åkerholm, M., Stark, S. et al. (2018)

Multiple feedbacks contribute to a centennial legacy of reindeer on tundra vegetation

Ecosystems (New York. Print), 21(8): 1545-1563

https://doi.org/10.1007/s10021-018-0239-z

Access to the published version may require subscription.

N.B. When citing this work, cite the original published paper.

Permanent link to this version:

http://urn.kb.se/resolve?urn=urn:nbn:se:umu:diva-142126 


\title{
Multiple Feedbacks Contribute to a Centennial Legacy of Reindeer on Tundra Vegetation
}

\author{
Dagmar Egelkraut, ${ }^{1 *} \odot$ Kjell-Åke Aronsson, ${ }^{2}$ Anna Allard ${ }^{3}$ \\ Marianne Åkerholm, ${ }^{3}$ Sari Stark, ${ }^{4}$ and Johan Olofsson ${ }^{1}$
}

\begin{abstract}
${ }^{1}$ Department of Ecology and Environmental Science, Umeå University, 90187 Umeå, Sweden; ${ }^{2}$ Ájtte, Swedish Mountain and Sami Museum, Jokkmokk, Sweden; ${ }^{3}$ Department of Forest Resource Management, Swedish University of Agricultural Sciences, Umeå, Sweden; ${ }^{4}$ Arctic Centre, University of Lapland, Rovaniemi, Finland
\end{abstract}

\begin{abstract}
Historical contingency is the impact of past events, like the timing and order of species arrival, on community assembly, and can sometimes result in alternative stable states of ecological communities. Large herbivores, wild and domestic, can cause profound changes in the structure and functioning of plant communities and therefore probably influence historical contingency; however, little empirical data on the stability of such shifts or subsequent drivers of stability are available. We studied the centennial legacy of reindeer (Rangifer tarandus) pressure on arctic tundra vegetation by considering historical milking grounds (HMGs): graminoid- and forb-dominated patches amid shrub-dominated tundra, formed by historical Sami
\end{abstract}

Received 19 October 2017; accepted 25 February 2018; published online 14 March 2018

Electronic supplementary material: The online version of this article (https://doi.org/10.1007/s10021-018-0239-z) contains supplementary material, which is available to authorized users.

Author contributions JO, KA and DE conceived the ideas and designed methodology; DE collected the field data; $\mathrm{MA}$ and AA performed the analysis of aerial photographs; SS was responsible for the soil analyses; DE and JO analyzed the data and led the writing of the manuscript. All authors contributed critically to the drafts and gave final approval for publication.

*Corresponding author; e-mail: dagmaregelkraut@gmail.com reindeer herding practices that ended approximately 100 years ago. Our results show that the core areas of all studied HMGs remained strikingly stable, being hardly invaded by surrounding shrubs. Soil nitrogen concentrations were comparable to heavily grazed areas. However, the HMGs are slowly being reinvaded by vegetative growth of shrubs at the edges, and the rate of ingrowth increased with higher mineral $\mathrm{N}$ availability. Furthermore, our data indicate that several biotic feedbacks contribute to the stability of the HMGs: increased nutrient turnover supporting herbaceous vegetation, strong interspecific competition preventing invasion and herbivore damage to invading shrubs. In particular, voles and lemmings appear to be important, selectively damaging shrubs in the HMGs. We concluded that HMGs provide clear evidence for historical contingency of herbivore effects in arctic ecosystems. We showed that several biotic feedbacks can contribute to subsequent vegetation stability, but their relative importance will vary in time and space.

Key words: alternative stable states; plant-herbivore interactions; historical contingency; land use legacy; plant-soil interactions; Rangifer tarandus; soil nutrients; vegetation composition. 


\section{HighLights}

- We used historical reindeer herding sites to assess stability of vegetation shifts

- Herbivore-induced shifts in vegetation and soil were stable for at least 100 years

- Plant-soil feedbacks and herbivore attraction aided stability of vegetation shifts

\section{INTRODUCTION}

The present state of an ecosystem may be highly dependent on abiotic and biotic events of the past, commonly referred to as historical contingency (Fukami 2015). Historical contingency effects in plant communities can be driven either by priority effects, meaning a strong influence of historical order of arrival and abundance of plant species on the present species composition (Slatkin 1974; Chase 2003), or by long-lasting changes in soil conditions (Jones and others 2004; Kardol and others 2007). These kinds of processes may, under some conditions, result in alternative stable states, when different historical sequences of species entering a location lead to different final community composition (Chase 2003). For a state to be stable, it should be resistant to colonization by species in the surroundings (Law 1999) unless heavily disturbed (Fukami 2015). State transitions can occur at large spatial scales, and it has been suggested, for example, that forests and savanna represent alternative states, in which the attractors are stabilized by a number of abiotic and biotic feedbacks (Hirota and others 2011; Staver and others 2011). Communities that have not reached a stable state, but still vary in structure and/or function because of historical species composition under the same environmental conditions, are instead called alternative transient stages (Fukami 2015).

Large herbivores, wild or domestic, are known to exert strong influences on both vegetation and soil processes in terrestrial systems (Milchunas and Lauenroth 1993; Bardgett and Wardle 2003) and have been shown to drive large-scale vegetation shifts (McNaughton 1984; Milchunas and others 1988; Ripple and Beschta 2012). Some of these herbivore-driven vegetation shifts appear stable over time or, it has been suggested, represent alternative stable states. Numerous mechanisms have been suggested to drive the formation of alternative stable states in grazing ecosystems. Theoretical analyses reveal that alternative stable states can arise from density-dependent plant-herbivore interactions alone (Noy-Meir 1975), but most recent examples include plant-soil feedbacks as a major component. Alternative stable states may arise when herbivory triggers a positive feedback between reduced plant density and reduced resource availability in semiarid systems (Rietkerk and van de Koppel 1997; van de Koppel and others 1997). Furthermore, alternative stable states may also be established when herbivores drive positive feedbacks on plant growth, that is, herbivores provide readily available nutrients, which favor fast growing plants that produce easily degradable litter that will further enhance nutrient cycling, favoring fast growing plants and attracting herbivores (McNaughton 1984; Hobbie 1992). However, although numerous studies have addressed these phenomena, there is still a poor understanding of the conditions under which herbivore-driven vegetation changes result in such strong priority effects or alternative stable states.

One example of dramatic vegetation changes in grazing ecosystems is the vegetation shift from mossor shrub-dominated tundra to graminoid-dominated vegetation that reindeer or caribou (Rangifer tarandus) can cause. These vegetation transitions are often caused by domesticated reindeer when concentrated by fences (Olofsson and others 2001, 2004), but are also found in the absence of fences (Forbes and others 2009; Tømmervik and others 2010), and with wild reindeer/caribou (Thing 1984; Manseau and others 1996; van der Wal and Brooker 2004). The shift from a shrub-dominated state to a more graminoid-dominated state can be attributed to a number of drivers such as reduced insulation of soils resulting in higher soil temperatures and higher nutrient turnover, increased fecal nutrient input, and tolerance to repeated defoliation and trampling which allows graminoids to outcompete shrub vegetation (van der Wal 2006). Since these shifts in vegetation are dramatic and relatively sudden, they have been characterized as alternative stable states (van der Wal 2006) and even linked to the largescale transition of Beringian ecosystems from grassdominated steppe to moss-dominated tundra at the end of the Pleistocene, which has been attributed to the extinction of the Pleistocene mega-herbivores (Zimov and others 1995b; Bakker and others 2016). Although the drivers of the vegetation shifts from moss or shrub-dominated tundra to graminoiddominated vegetation are reasonably well under- 
stood, much less is known about the subsequent stability of the vegetation states. A transplantation study between high and low reindeer density areas showed that the heath vegetation can change into graminoid-dominated vegetation in just a few years, although such graminoid-dominated vegetation is fairly stable even in the absence of active grazing during the first decade after herbivore removal. This was interpreted as a priority effect linked to the dense grass swards being hard to invade (Olofsson 2006). However, like many other systems where strong historical contingency, priority effects and alternative stable states are discussed (Fukami 2015), and knowledge of conditions that deliver such effects, as well as empirical data on the stability of states, are lacking (Beisner and others 2003).

Here, we used so-called historical milking grounds (hereafter: HMGs) to assess the legacy of herbivoreinduced vegetation shifts on a centennial timescale. HMGs are clearly visible patches of graminoid- and forb-dominated vegetation in an otherwise shrubdominated tundra vegetation. They are the result of a historical ( 1350 to 1900 AD) Sami reindeer husbandry practice, when summer herding was an intensive practice and of nomadic nature (Aronsson 1991; Tømmervik and others 2010). The same locations in the landscape were occupied regularly, causing heavy and persistent vegetation changes on a small local scale. Although the active use of HMGs ceased about a century ago when reindeer management shifted into a more extensive herding form, they are still clearly recognizable in the north-Scandinavian mountain landscape as large oval-shaped patches. They are dominated by graminoids and forbs, and the border between the graminoid- and surrounding vegetation is typically a sharp transition occurring across a few $\mathrm{cm}$.

To study the long-term stability of vegetation changes, experiments that typically barely cover more than a few decades will not be sufficient. The HMGs described above offer a rare opportunity to study the drivers of vegetation change stability at a centennial timescale. We studied the long-term legacy of high reindeer densities by investigating 14 HMGs and evaluating their persistence, vegetation composition, soil properties and present use by herbivores. We tested the following hypotheses: (1) the grass- and forb-dominated HMGs are stable vegetation states, which have not been reinvaded by shrubs during the last century since active use ceased. (2) The nutrient availability for plants is still higher in HMGs compared to control sites even a century after active use ceased. (3) The higher soil nutrient availability is driven by a positive feedback of plants producing higher quality litter, rather than by a larger total nutrient pool. (4) HMGs function as feeding hotspots for herbivores, which supports the stability of the vegetation and soil processes therein.

\section{Materials AND Methods}

\section{Historical Reindeer Husbandry}

Reindeer husbandry is a common land use practice in most parts of the Eurasian arctic and some parts of the subarctic (Uboni and others 2016). In Scandinavia, current reindeer husbandry is categorized as extensive with relatively free moving groups of reindeer during summer. However, until about a century ago, reindeer husbandry was more intensive, and involved daily gathering of reindeer for milking (for example, for cheese production), in addition to calf marking and slaughtering (Aronsson 1991). Milking of the reindeer typically took place from calving in spring through September (Beach 1981). This form of reindeer husbandry required reindeer to be tame and held in gathered herds (Figure 1). Herders traveled with the reindeer, following a nomadic lifestyle, recurrently occupying the same locations over the centuries. At those locations, the presence of closely gathered herds resulted in higher levels of grazing, trampling and feces deposition in a restricted area, which in turn resulted in distinct patches of herbaceous vegetation in a shrub-dominated landscape. These patches were never enclosed by fences, and there are no signs of fire ever being used to clear the sites. They can still be recognized today, and because milking the reindeer was a central part of this herding practice (Linné 1732; von Düben 1873), we here refer to these sites as historical milking grounds (HMG, renvall in Swedish). Each herder used a number of HMGs, and not all of them were used every year. The herd would typically stay at a HMG for a maximum of a few weeks, to prevent the plant roots being too severely damaged by trampling, and to avoid the build-up of reindeer pathogens and parasites in the soil. This means that large networks of HMGs were created in the low alpine zone in most larger valleys in the Scandinavian mountains, although the possibilities to detect them depend on later land use. HMGs are generally positioned on small ridges or higher elevated areas (which have limited productivity), to allow for a better view of the area and increase wind exposure to reduce discomfort caused by mosquitoes. At one end, where the tent was erected, they included a fireplace, the remains of which often can be found today. HMGs were used not only as grazing grounds and for the milking of 


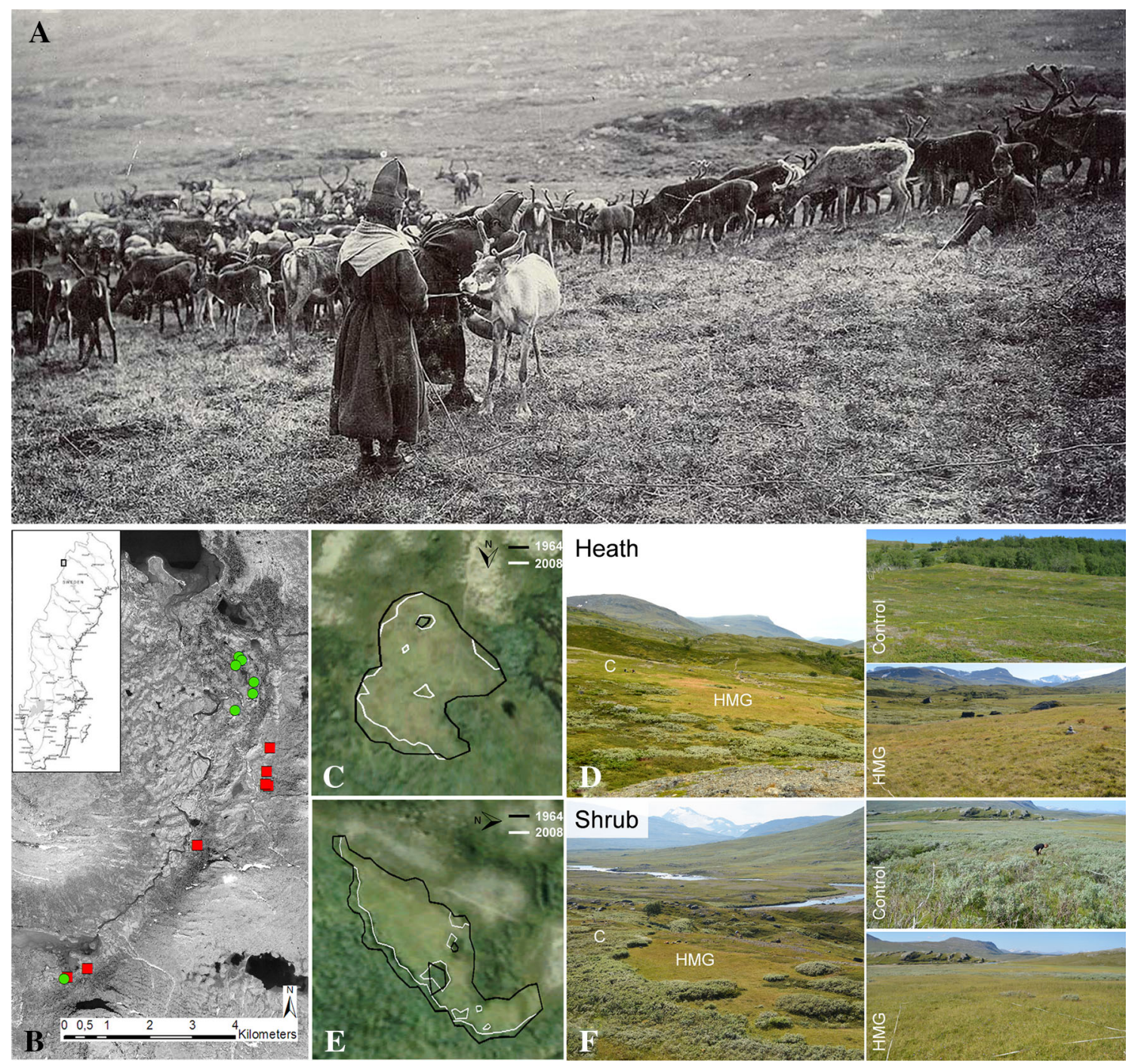

Figure 1. Historical reindeer husbandry and an overview of the study site. A Sami milking and herding reindeer in a milking ground, Sarek, 1902 (photograph: Axel Hamberg; Axel Hambergsamlingen, Uppsala University Library). Especially noteworthy are the closeness of the herd, and the dense graminoid-dominated vegetation even during active use of the milking ground. B Overview of the research area, showing lake Virihaure in the north, and the locations of the 14 historical milking grounds (heath sites indicated by green circles and shrub sites by red squares); C, E two examples of HMG outlines based on 1964 and 2008 imagery projected onto a satellite image. Surface area of these HMGs was $1855 \mathrm{~m}^{2}$ (C) and $1146 \mathrm{~m}^{2}(\mathbf{E})$ in 2008. Areas between the black outer and white inner lines are referred to as transition zones; $\mathbf{D}, \mathbf{F}$ the same HMGs in 2013, the location of HMG and control plots are indicated (HMG and C); and a closer look on the vegetation structure in both types (photographs: Dagmar Egelkraut). Images c and d show a heath site; images $\mathbf{E}$ and $\mathbf{F}$ show a shrub site.

reindeer, but also for the collection of edible plants such as Rumex acetosa, which is otherwise scarce in the dominant tundra vegetation (Staland and others 2011). Collection of woody material for firewood is expected, but most wood was probably collected outside of the HMGs, close to streams and lakes where patches of forest and larger shrubs are found. The impact of the collection of edible plants is not known, but expected to be small.
Although the active use of these HMGs ended between 1900 and 1920 in our study region, the sharp changes in vegetation can still be recognized in the tundra landscape today. The use of HMGs ceased as intensive reindeer herding was replaced by extensive herding (Manker 1947) and the herders adapted to a more settled lifestyle in which they started to keep goats for supplementary milk production and reindeer mainly for meat production. Across our study site, the HMGs are spatially 
separated from these later forms of land use. Importantly, although the region is still used for reindeer grazing today, the extensive reindeer grazing results in reindeer spreading over vastly larger areas. The grazing pressure on the HMGs is therefore several orders of magnitudes lower compared to when they were actively grazed, and the present grazing pressure is far from being high enough to cause similar heath-graminoid transitions today.

Even though we know almost exactly when the active use of HMGs ceased, it is more difficult to determine when they were created. We assume that most of them were used during the period between 1600 and $1900 \mathrm{AD}$ because this is the period for which there is good evidence of widespread intensive reindeer herding and a fairly large number of domesticated reindeer (Forbes 2006; Aronsson 2009), although well-developed milking of reindeer was described as early as 1518 (Olaus 1555). Domestication of reindeer in northern Scandinavia likely has a much older history (Manker 1947; Ruong 1982; Lundmark 2007; Bergman and others 2008), and the oldest HMGs may date back to at least 1350, based on pollen analyses showing increases in herbs and graminoids associated with trampling and grazing (Karlsson 2008), using excavations and pollen analyses (Andersen 2017) and earlier paleoecological studies (Aronsson 2009; Wallin and Aronsson 2012).

\section{Study Area and Site Selection}

This study took place in Padjelanta (Badjelánnda) National Park $\left(1984 \mathrm{~km}^{2}\right)$, which is located in the Tuorpon reindeer district (sameby in Swedish) in northern Sweden. Our study area in the center/south of Padjelanta NP is above the tree line and mostly covered by tundra heath (dominated by Betula nana and Empetrum nigrum) and shrub (dominated by Salix glauca and S. lapponum) vegetation. The study area is used by reindeer mostly during the months of June and July. Reindeer numbers in Tuorpon $\left(13,180 \mathrm{~km}^{2}\right)$ are currently between 5000 and 6000 animals, 1994-2001 (Sametinget 2016), see Appendix 1 in ESM. Other common herbivores in the area are ptarmigan (Lagopus lagopus and L. muta), lemmings (Lemmus lemmus), voles (predominantly gray-sided vole Myodes rufocanus), and to a much lesser extent mountain hare (Lepus timidus) and moose (Alces alces), mostly in autumn. The soil sediments in the study area are fairly heterogeneous, but are dominated by glacial tills and sorted fluvial deposits. As typical for arctic soils, only weak podzolic profiles are developed. However, there are signs of cryogenic activity in many sites. Average yearly temperatures in the Padjelanta have increased from - 1.8 to $0.5^{\circ} \mathrm{C}$ between 1961 and 2014 , and average July temperatures increased from 9.7 to $12^{\circ} \mathrm{C}$ during that period. Average yearly precipitation is $968 \mathrm{~mm} \mathrm{y}^{-1}$ with approximately $92 \mathrm{~mm}$ falling in July (SMHI 2016). Appendix 1 in ESM shows the data pertaining to temperature, precipitation and reindeer over recent decades.

We selected 14 HMGs in the area between the cabins Staloluokta (N 67.318108, E 16.697541) and Staddajåkkå (N 67.240899, E 16.591257) for this study, of which seven were surrounded by heathtype vegetation and seven by shrub-type vegetation. The selected sites were in altitudes between 634 and $741 \mathrm{~m}$ a.s.l. All these sites are situated above the present tree line which is typically found at about $620 \mathrm{~m}$ a.s.l., although forest patches can be found at higher altitudes in places with a favorable microclimate. All HMGs were originally identified by the Ájtte Museum during a field survey supported by the Swedish National Heritage Board, which took place mostly in 2008 with some complementary work in the following years (Aronsson and Israelsson 2008). The HMGs used in this study were selected in the field in 2013. They needed to be large enough to accommodate a $5 \times 10 \mathrm{~m}$ inventory plot (placed in the center of the HMG) and have the possibility of selecting a suitable control plot nearby. HMGs are typically located on ridges and higher elevated areas (Figure 1). These ridges are nutrient poor and do not normally support lush herbaceous vegetation, thus supporting that the HMGs indeed are formed by the historical grazing regime.

The control plots were chosen to be representative for the tundra outside HMGs. Because this is a cultural landscape, the whole area has been influenced by human land use during the last millennia, albeit much less intense than the land use in the HMGs. We see, however, no indications in the vegetation today that the chosen control plots should have been more intensively used or grazed than similar tundra sites further away from the HMGs. We chose a paired control plot at a close proximity of each HMG (on average $50 \mathrm{~m}$ away) in a comparable site with respect to aspect, hydrology, sediment and elevation of the corresponding HMG. All differences in vegetation and the soil organic layer between HMGs and controls should thus originate from the difference in land use history and are unlikely due to differences in bedrock or climate between the treatments. The close prox- 
imity may involve the risk that the control sites were subject to a more intense historical land use than the landscape as a whole, but have no support for this being the case. The vegetation in the control plots has no visible signs of historical land use, and there are no visible vegetation gradients over that distance from HMGs, but rather in a few meters distance from regrowing borders. In addition to control- and HMG plots, we used historical and modern aerial photographs to identify the transition zones for each HMG: areas of the HMGs that have been reinvaded by shrubs in recent decades (Figure 1C, E). Nine transition zones, of which four were located in shrub- and five in heath vegetation, were large enough to fit a $5 \times 10$ m inventory plot and could thus be studied in more detail.

\section{Aerial Photograph Analysis}

To assess the stability of the HMGs over time, we analyzed high-resolution aerial photographs of the study area from the years 1964 and 2008 (C) Lantmäteriet [I2014/00764]). The locations of the HMGs were confirmed based on ground data collected during the field survey. The photographs were then interpreted stereoscopically, starting with outlining the milking grounds in the aerial photographs from 1964. These were then copied onto the layer for 2008 and changed where clear deviations in vegetation could be perceived, using the programs ArcGIS and Summit Evolution, on a Planar screen for interpreting in stereo. Using the image analyses, we were able to calculate the total area of each HMG, as well as the percentage of surface change over time. Additionally, we calculated the inward advance of the border in $\mathrm{cm} \mathrm{y}^{-1}$ over the period 1964-2008, in all studied HMGs. This was done by selecting 32 evenly distributed points along each 1964 border and measuring the shortest distance to the 2008 border. We were also able to identify reinvaded parts of HMGs (transition zones), where the heath or shrub edge had encroached into the HMG during the last 44 years. Lastly, we calculated the unevenness of each border in 1964 (Border Unevenness Index) to test whether uneven HMGs with a higher border-area ratio would be invaded faster; see Appendix 2 in ESM for the formula used.

\section{Vegetation Surveys}

Vegetation composition surveys of all HMG and control plots were conducted from July 23, to $\mathrm{Au}-$ gust 15, 2013, and transition zones were inventoried between July 22 and August 4, 2015. We placed a 10-pin point frame (pin diameter $2.5 \mathrm{~mm}$, distance between pins $5.5 \mathrm{~cm}$ ) in an evenly spaced grid at 40 locations within each $5 \times 10 \mathrm{~m}$ plot, resulting in 400 points per plot. Every living leaf or stem touched by a pin was identified to species level, except for sedges that were lumped to genus, since intermingling leaves without floral shoots made species determination of all hits too demanding. Ground cover was recorded as moss (to genus level), lichen (to genus level) and/or bare soil, rock or litter. Additionally, we measured vegetation height at the middle of each point frame, 40 times per plot.

\section{Soil Analyses}

We measured soil temperature at a depth of $12 \mathrm{~cm}$ in five random locations per plot. Further, we collected samples of the whole organic layer $(\mathrm{O}+\mathrm{A}$ horizon) by taking 10 soil cores (diameter: $2.5 \mathrm{~cm}$ ), evenly spread throughout each plot. All sites have clearly developed organic layers $(\mathrm{O}+\mathrm{A}$ horizons $)$ indicating only limited mixing. We measured the depth of the organic layer in each core and stored the cores from the same plot in an airtight plastic bag. Because of field condition limitations, the samples were kept cool at soil temperature (approximately $10^{\circ} \mathrm{C}$ ) until they could be frozen, a maximum of 1 week later. Before analysis, the soil samples were thawed and sieved through a $2-\mathrm{mm}$ sieve and bulked per plot. Subsamples were then analyzed for microbial, soluble organic and mineral $\mathrm{N}$ and $\mathrm{P}$, total $\mathrm{C}$ and $\mathrm{N}, \mathrm{pH}$ and soil moisture. We analyzed extractable microbial, soluble organic and mineral $\mathrm{N}$ and $\mathrm{P}$ contents by shaking $2 \mathrm{~g}$ fresh soil in $50 \mathrm{ml} 0.5 \mathrm{M} \mathrm{K}_{2} \mathrm{SO}_{4}$ solution $(2 \mathrm{~h})$ before filtering. The extract was analyzed colorimetrically (Bremner 1965) using automated flow injection (FIA star 5000, FOSS Analytical, Denmark) to obtain extractable inorganic $\mathrm{N}$ and $\mathrm{P}\left(\mathrm{NO}_{3}-\mathrm{N}, \mathrm{NH}_{4}-\mathrm{N}\right.$, $\mathrm{PO}_{4}-\mathrm{P}$ ). To retrieve total extractable $\mathrm{N}$ and $\mathrm{P}$ concentrations, all extractable $\mathrm{N}$ and $\mathrm{P}$ in the extract were oxidized to $\mathrm{NO}_{3}$ and $\mathrm{PO}_{4}$ (Williams and others 1995), and then analyzed as described above. For microbial $\mathrm{N}$ and $\mathrm{P}$, soil samples were fumigated (chloroform, $18 \mathrm{~h}$ ) prior to extraction and $\mathrm{N}$ and $\mathrm{P}$ analysis conducted as described above (Brookes and others 1985). Microbial biomass N and P were then calculated by subtracting the total extractable inorganic $\mathrm{N}$ and $\mathrm{P}$ from the extractable $\mathrm{N}$ and $\mathrm{P}$ of the fumigated samples. Following Brookes and others (1985), we used a correction factor, dividing by 0.54 to account for incomplete fumigation. For total $\mathrm{C}$ and $\mathrm{N}$, samples were dried at $70^{\circ} \mathrm{C}$ for $18 \mathrm{~h}$ and milled using a ball mill. They were then converted to $\mathrm{CO}_{2}$ and $\mathrm{N}_{2}$ by 
combustion using an Elemental Analyzer (Flash EA 2000, Thermo Fisher Scientific, Bremen, Germany). All values obtained (C, N and $\mathrm{P}$ ) were recalculated to $\mathrm{g} \mathrm{m}^{-2}$. Soil $\mathrm{pH}$ was measured by extracting $2 \mathrm{~g}$ fresh soil in $50 \mathrm{ml} 1 \mathrm{M} \mathrm{KCl}$ solution. The samples were shaken for $2 \mathrm{~h}$ and left to settle overnight before measuring $\mathrm{pH}$ (Corning Model $220 \mathrm{pH}$ meter). Moisture content was analyzed as gravimetric weight loss after drying the soils overnight $(12 \mathrm{~h})$ at $105^{\circ} \mathrm{C}$, and the organic matter content was determined by loss on ignition $\left(475^{\circ} \mathrm{C}\right.$, $4 \mathrm{~h})$.

\section{Herbivore Presence and Browsing Damage}

We monitored vertebrate herbivore presence in HMGs and control plots using dung counts and trampling indicators. In each $5 \times 10 \mathrm{~m}$ inventory plot, four smaller dung plots of $1 \mathrm{~m}^{2}$ were cleared of dung in late June 2014. In July 2015 and July 2016 , they were revisited and cleared of dung. The number of droppings of moose, reindeer and ptarmigan, and number of dropping piles of small rodents like lemming and voles, were recorded. During the same timeframe, we placed four small plots of 25 trampling indicators in a $25 \times 25 \mathrm{~cm}$ grid in each plot, to assess trampling pressure. The trampling indicators are nails pushed down into the soil and then lifted up one $\mathrm{cm}$. Trampling indicators that had been pushed down into the soil were recorded as indications of trampling in 2015 and 2016. These trampling indicators are a robust method to estimate trampling (Olofsson and others 2004; Sitters and others 2017), but cannot separate reindeer from other herbivores or humans.

In addition to herbivore presence, we assessed vertebrate and invertebrate browsing damage on 20 shrubs in each control plot, along stable borders and on single shrubs within each HMG. At the heath sites, we assessed Betula nana and at the shrub sites we assessed Salix spp. (S. glauca or $S$. lapponum). In the controls and along stable borders, we selected five shrubs ( $1 \mathrm{~m}$ apart) along a $4 \mathrm{~m}$ transect, repeated four times, resulting in 20 shrubs assessed in each control and 20 along stable borders. Inside the HMGs, we selected as many individual shrubs as could be found, up to 20. Each of these shrubs was assessed for the following types of browsing damage: (1) percentage top shoots damaged by reindeer or frost; (2) percentage top shoots browsed by small rodents; (3) invertebrate herbivory on leaves; and (4) visible damage to bark caused by small rodents. Reindeer typically rip the leaves off the top shoots, leaving most of the woody parts behind. The ragged look is typical, but is sometimes hard to distinguish from possible occasional moose browsing or frost damage, especially when the damage is older than a year. We therefore grouped all damaged top shoots together in the group "Top shoot damage (frost/reindeer/moose)." Browsing damage on top shoots caused by small rodents can be easily distinguished by the sharp cuts that they make and damage on the bark leaves clear traces of their teeth. Most of this damage is caused by voles and lemmings, but on thinner branches, damage from hares could not always be differentiated. To assess invertebrate herbivory, we randomly picked five leaves per individual, resulting in 100 leaves per treatment per site, which were pressed and dried. We quantified the percentage damage to the leaves using a protocol developed by the Herbivory Network (Barrio and others 2016, 2017). Each leaf was carefully examined to detect damage by different types of herbivores and was quantified into different percentage classes (undamaged, $<1,<5,<25,<50$, $<75,<100 \%)$.

\section{Statistical Analyses}

We used paired t tests to determine whether the HMG surface areas had changed between 1964 and 2008 and a $t$ test to determine whether the surface change differed between heath or shrub plots. Additionally, we used a multiple linear regression to test the relative shrub encroachment (\% surface decrease) in relation to mineral $\mathrm{N}$ availability, border unevenness, area and HMG vegetation density. Because the borders in the zone between two neighboring HMGs were not clear in the 1964 aerial photograph, we could only determine a collective ingrowth for these two HMGs. They are thus treated as one point in this analysis. One outlier was removed following model diagnostics to avoid heteroscedasticity.

The vegetation composition in controls, transition zones and HMGs $(n=14,9$ and 14, respectively) were analyzed with a NMDS, using the meta-MDS function in the vegan package (Oksanen and others 2015) in the statistical package R (R Core Team 2013). We used species composition per plot based on vascular plants only. In cases where not all individuals could be specified to species level, we grouped the plants to genus level, as follows: Agrostis capillaris and A. mertensii; Carex spp.; Festuca ovina and F. rubra; Poa spp. (predominantly P. alpina and P. pratensis); Pyrola minor and P. major; and Salix spp. (S. glauca and S. lapponicum). For the analysis, species occurring in only one plot were 
removed. In addition to the NMDS, we grouped the plants into plant functional types (graminoids, forbs, evergreen dwarf shrubs, deciduous dwarf shrubs, deciduous shrubs, pteridophytes and in this case also bryophytes (Chapin and others 1996). We tested for differences in abundance per plant functional type between control and HMG using paired t tests on log-transformed data.

The soil properties data as well as the herbivore visitation data were examined using ANOVA, including site vegetation type (heath or shrub) and treatment (control or HMG) as factors and using site number as an error factor. Significant interaction effects between vegetation type and treatment were further examined using a paired t test to compare the difference between control and HMG in each vegetation type, separately. Browsing damage to shrubs was also examined using ANOVA, including the factors vegetation type (heath or shrub) and treatment (control, border or HMG).

\section{RESUlts}

The average size of HMGs, estimated from aerial photographs, decreased during the last five decades from $4255.7 \mathrm{~m}^{2} \pm 1042.2$ (SE) in 1964 to $3423.9 \mathrm{~m}^{2} \pm 759.8$ in 2008 . This translates to a relative decrease in surface area of $17.5 \% \pm 4.3$ over 44 years and an absolute movement rate of the border of $0.05 \mathrm{~m} \mathrm{y}^{-1} \pm 0.01$. The decrease in surface area was never homogenous along the whole border, with some parts of the borders being stable and other parts unstable (Figure 1C, E). There was no difference in encroachment rate between HMGs located in heath versus shrub habitat (t test, $p=0.556)$. However, the relative encroachment as \% surface decrease was, in a multiple regression $\left(R^{2}=0.828\right)$, positively related to mineral $\mathrm{N}$ availability (Figure $2 \mathrm{~A}$ ), unevenness of the border (Figure 2B) and HMG area (Figure 2C). Although several HMG borders showed shrub encroachment into the HMG to a certain extent, the core areas remained largely unchanged between 1964 and 2008 as far as could be detected based on the aerial photographs.

The vascular plant species composition in the HMGs was clearly different from their control plots (Figure 3). Moreover, the control plots were clearly separated into two groups, hereafter called heath and shrub vegetation types, with non-overlapping ranges in the NMDS (Figure 3). Control sites in the heath vegetation were characterized by dwarf shrubs such as Empetrum nigrum hermaphroditum and Betula nana, and control sites in the shrub vegetation were strongly associated with taller shrubs like Salix spp. as well as graminoids and tall forbs like Geranium sylvaticum and Trollius europaeus (Figures 3, 4; Table 1 and Appendix 3 in ESM). The HMGs occurring in these two distinctly different vegetation types were much more similar to each other, as indicated by clearly overlapping NMDS ranges (Figure 3). All HMGs were predominantly dominated by turf-forming graminoids of the genera Carex, Festuca and Deschampsia, as well as low forbs, for example, Rumex acetosa lapponicus (Figure 4, Appendix 3 in ESM). Heath-type HMGs also had a higher abundance of feather mosses, and shrub-type HMGs exhibited the same trend (Figure 4; Table 1, Appendix 3 in ESM). The transition zones, that is, the areas classified as milking
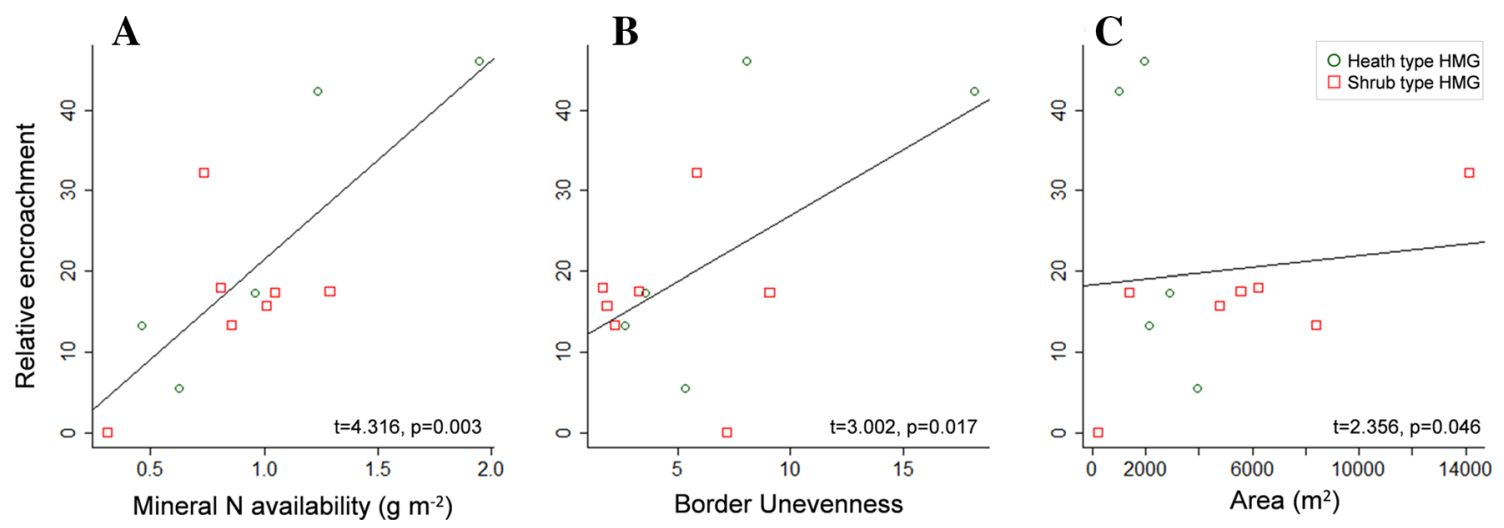

Figure 2. Relative encroachment (\% HMG surface decrease) between 1964 and 2008 in relation to A current mineral N availability $\left(\mathrm{g} \mathrm{m}^{-2}\right)$ in the HMG soil, B unevenness of the border in 1964 and C HMG area $\left(\mathrm{m}^{2}\right)$ in 1964 . The green circles represent heath sites, red squares are shrub sites. The $t$ and $p$ values in each graph represent the outcomes of a multiple linear regression testing the relative shrub encroachment (\% surface decrease) in relation to mineral $\mathrm{N}$ availability, border unevenness, area and HMG vegetation density. 


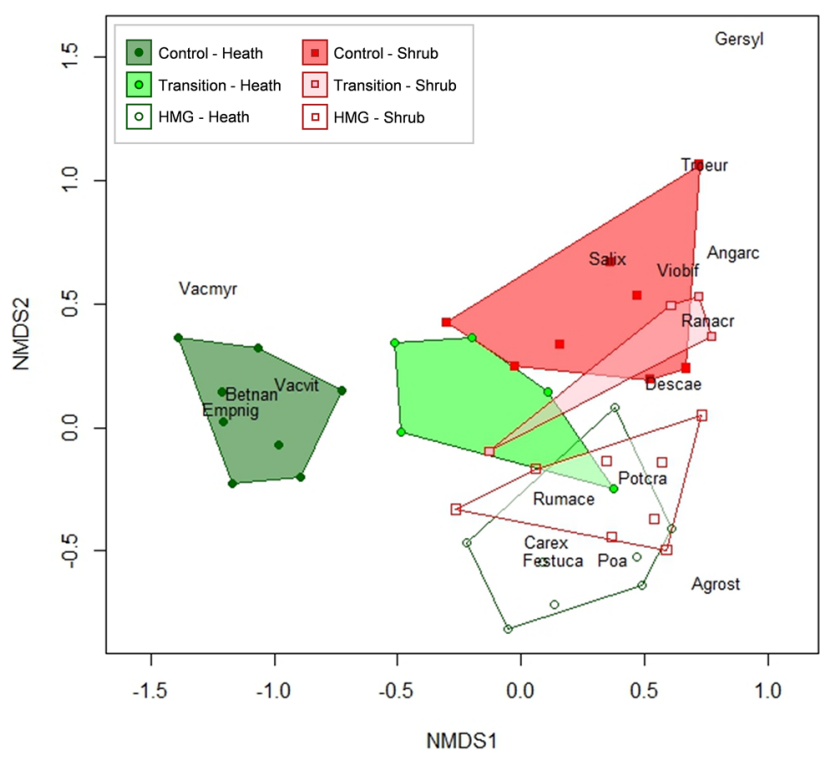

Figure 3. NMDS ordination based on the species composition of vascular plants in HMGs, control plots and if applicable, transition zones. Green circles represent heath sites, and red squares are shrub sites. The ranges are outlined per treatment: open polygons for HMGs, light green and light red for transition zone plots and dark green and dark red for control plots. Plant species highlighted are: Angarc, Angelica archangelica; Agrost, Agrostis capillaris/mertensii; Betnan, Betula nana; Carex, Carex spp.; Descae, Deschampsia caespitosa; Empnig, Empetrum nigrum hermaphroditum; Festuca, Festuca ovina/rubra; Gersyl, Geranium sylvaticum; Ranacr, Ranunculus acris; Poa, Poa spp.; Potcra, Potentilla crantzii; Rumace, Rumex acetosa lapponicus; Salix, Salix glauca/lapponum; Troeur, Trollius europaeus; Vacmyr, Vaccinium myrtillus; Vacvit, Vaccinium vitis-idaea; Viobif, Viola biflora. A complete overview of all plant species and abundances is provided in Appendix 4 in ESM.

grounds in 1964 but not in 2008, had a plant community composition intermediate between control plots and HMGs, though it appears that the transition zone in the heath vegetation type was more similar to the HMGs and the transition zone of the shrub vegetation type was more similar to the control plots (Figure 3). Finally, the vegetation was taller in the HMGs than in the controls in the heath vegetation type $(17.3 \mathrm{~cm} \pm 3.5$ (SE) and $8.6 \mathrm{~cm} \pm 1.1$, respectively), but shorter in the HMGs compared to the controls in the shrub vegetation type $(20.8 \mathrm{~cm} \pm 4.9$ and $42.5 \mathrm{~cm} \pm 7.7$, respectively) (ANOVA; site type (heath or shrub) $F_{1,12}=10.040, p=0.008$ and interaction effect type $\times$ treatment $F_{1,12}=16.381, p=0.002$ ).

The availabilities of both soluble organic $\mathrm{N}$ and mineral $\mathrm{N}$ in soils were higher in the HMGs than the controls in heath vegetation type, but lower in the HMGs compared to the controls in shrub vegetation type (Figure 5; Table 2, significant vegetation type $\times$ treatment). In both heath and shrub vegetation types, mineral $\mathrm{P}$ availability and $\mathrm{C} / \mathrm{N}$ ratios were lower in the HMGs (Figure 5F, H). Soil moisture was also lower in the HMGs but especially in the heath vegetation types (Figure 5K), and soil temperature was higher in heath plots compared to shrub plots (Figure 5L). Not shown in Figure 5 is the organic matter content (\%) of the soils, which was lower in the HMGs than in the controls in the heath-type vegetation $[24.8 \% \pm 3.1 \quad$ (SE) and $48.8 \% \pm 6.9$, respectively], but similar in the HMGs and controls of the shrub-type vegetation $(45.1 \% \pm 5.5$ and $46.5 \% \pm 5.8$, respectively $)$ (Table 2).

There was no statistically significant difference in reindeer activity between HMGs and control plots recorded by the trampling indicators (Figure 6A) and through dung counts (Figure 6B), although there were tendencies for higher activity in HMGs of the shrub-type vegetation than in the corresponding controls. The deposition of small rodent droppings was highest in the control plots and in the shrub-type vegetation (Figure 6C). However, browsing damage caused by rodents on the dominant shrub species (either Betula nana or Salix spp.), measured as both frequency of cut top shoots and bark damage, was higher in the HMGs than in the controls or border zones in both vegetation types (Figure 6E, G; Table 3). Top shoot damage caused by frost, moose or reindeer and invertebrate herbivory on leaves was lower on Betula nana in the heath-type vegetation compared to Salix spp. in the shrub types (Figure 6D, F), but there were no differences between controls, borders or HMGs (Table 3). 

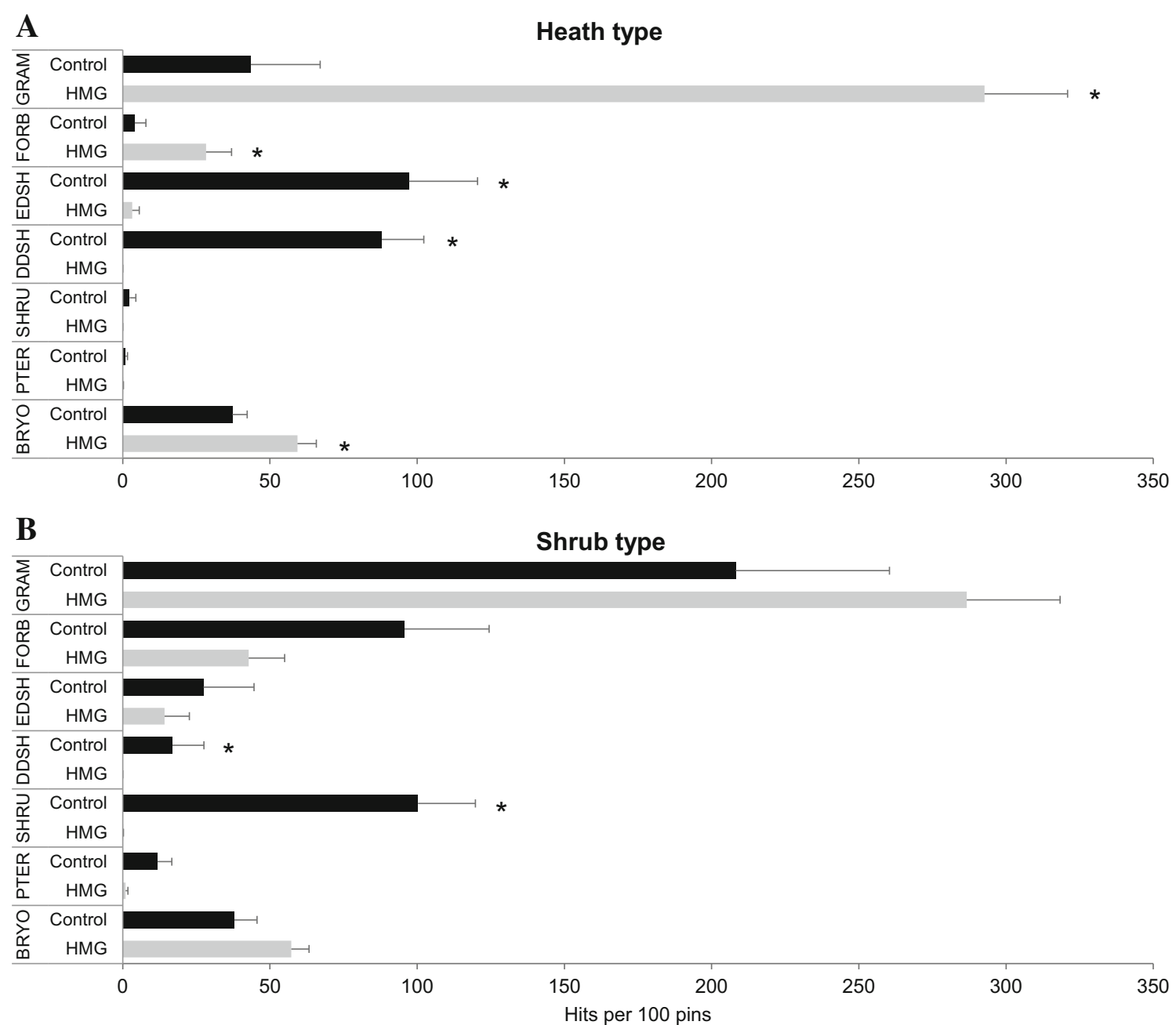

Figure 4. Vegetation composition of plant functional types in controls and HMGs, in $\mathbf{A}$ heath and $\mathbf{B}$ shrub habitats. The data are averaged to hits per 100 pins + SE, $n=7$. Significantly higher abundance $(p<0.05)$ in either control or HMG per plant functional type is indicated with *, tested using paired $t$ tests on log-transformed data. GRAM, graminoids; FORB, forbs; $E D S H$, evergreen dwarf shrubs; $D D S H$, deciduous dwarf shrubs; SHRU, deciduous shrubs; PTER, pteridophytes; $B R Y O$, bryophytes. A summary of the three most common species and abundances per plant functional type is provided in Appendix 3 in ESM.

Table 1. Effects of Treatment on Species Abundance per Plant Functional Type

\begin{tabular}{|c|c|c|c|c|c|c|}
\hline \multirow{2}{*}{$\begin{array}{l}\text { Habitat type } \\
\text { Plant functional type }\end{array}$} & \multicolumn{3}{|l|}{ Heath } & \multicolumn{3}{|l|}{ Shrub } \\
\hline & $t$ & $d f$ & $p$ & $t$ & $d f$ & $p$ \\
\hline Graminoids & -5.3164 & 6 & $0.002 * *$ & -1.4386 & 6 & 0.2 \\
\hline Forbs & -2.9076 & 6 & $0.027 *$ & 1.9821 & 6 & $0.095^{+}$ \\
\hline Evergreen dwarf shrubs & 3.0291 & 6 & $0.023 *$ & 0.9674 & 6 & 0.371 \\
\hline Deciduous dwarf shrubs & 79.2739 & 6 & $0.000 * * *$ & 2.7341 & 6 & $0.034^{*}$ \\
\hline Deciduous shrubs & 1.5396 & 6 & 0.175 & 7.0614 & 6 & $0.000 * * *$ \\
\hline Pteridophytes & 1.4242 & 6 & 0.204 & 2.6293 & 6 & $0.039 *$ \\
\hline Bryophytes & -3.4274 & 6 & $0.014^{*}$ & -2.2765 & 6 & 0.063 \\
\hline
\end{tabular}

The data, total hits per plot $(n=7)$ per plant functional group were log-transformed and examined using paired tests. Significant differences $(p<0.05)$ are marked in bold. Significance levels: ${ }^{* * *} p<0.001 ; * * p<0.01 ; * p<0.05 ;{ }^{+} p<0.1$. 

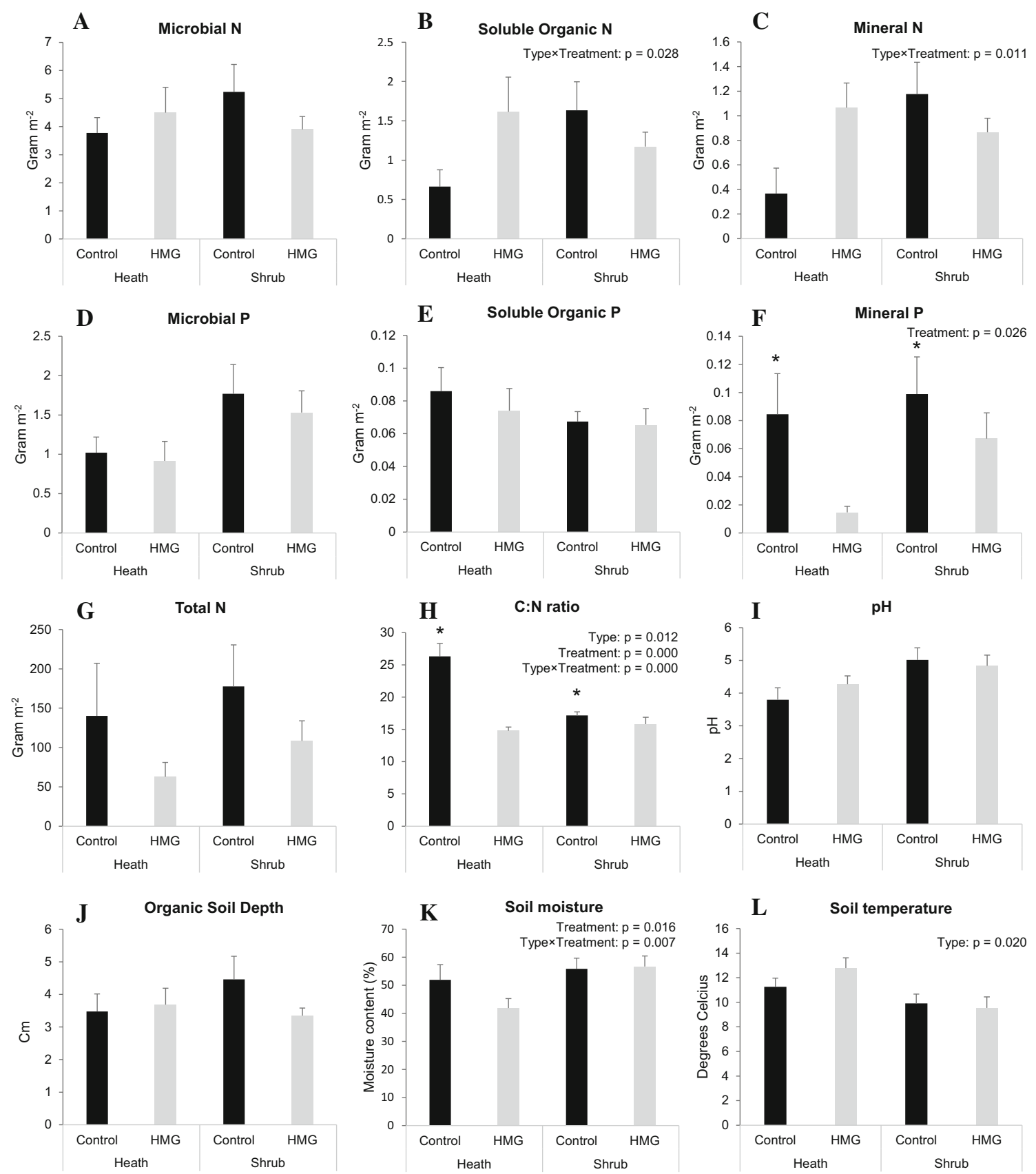

Figure 5. Properties of the organic soil layer in control and HMG, for heath and shrub habitats. Data shown are mean + SE, $n=7$. *Indicates significant treatment effects of HMG versus control $(p<0.05)$. Significant outcomes of ANOVA testing treatment (control/HMG) and type (heath/shrub habitat) using site number as a random factor are included with their $\mathrm{p}$ values.

\section{Discussion}

We studied the long-term persistence of a vegetation change induced by a concentration of reindeer during times of intensive reindeer husbandry in the Scandinavian mountain tundra. Our results show that the historical milking grounds (HMGs) have been remarkably stable over the last century. The vegetation composition and soil properties are not only distinctly different from the surroundings a century after active use ceased, but also strikingly similar to the conditions presently found in sites heavily grazed by domesticated reindeer, where the grazing, feces deposition and trampling is more than a order of magnitude higher than what is presently found in the HMGs (Sitters and others 
Table 2. Effects of Vegetation Type and Treatment on Organic Soil Properties

\begin{tabular}{|c|c|c|c|c|c|c|}
\hline \multirow[b]{2}{*}{ Variable } & \multicolumn{2}{|c|}{$\begin{array}{l}\text { Vegetation type } \\
\text { (heath/shrub) }\end{array}$} & \multicolumn{2}{|c|}{$\begin{array}{l}\text { Treatment } \\
\text { (control/HMG) }\end{array}$} & \multicolumn{2}{|c|}{$\begin{array}{l}\text { Interaction } \\
(\text { type } \times \text { treatment })\end{array}$} \\
\hline & $F_{1,12}$ & $p$ & $F_{1,12}$ & $p$ & $F_{1,12}$ & $p$ \\
\hline Microbial N & 0.260 & 0.620 & 0.260 & 0.643 & 2.573 & 0.135 \\
\hline Soluble organic N & 0.567 & 0.466 & 0.751 & 0.403 & 6.287 & $0.028 *$ \\
\hline Mineral N & 1.713 & 0.215 & 1.344 & 0.269 & 9.142 & $0.011^{*}$ \\
\hline Microbial P & 3.569 & $0.083^{+}$ & 1.057 & 0.324 & 0.160 & 0.696 \\
\hline Soluble organic $\mathrm{P}$ & 1.100 & 0.315 & 0.524 & 0.483 & 0.261 & 0.619 \\
\hline Mineral $\mathrm{P}$ & 2.032 & 0.179 & 6.504 & $0.026 *$ & 0.917 & 0.357 \\
\hline Total N & 0.617 & 0.447 & 4.126 & 0.065 & 0.013 & 0.910 \\
\hline $\mathrm{C} / \mathrm{N}$ ratio & 8.825 & 0.012 * & 42.450 & $0.000 * * *$ & 26.590 & $0.000 * * *$ \\
\hline $\mathrm{pH}$ & 4.373 & $0.058^{+}$ & 0.541 & 0.476 & 2.697 & 0.126 \\
\hline Organic soil depth & 0.316 & 0.585 & 0.930 & 0.354 & 2.005 & 0.182 \\
\hline Soil moisture & 2.886 & 0.115 & 7.889 & $0.016^{*}$ & 10.777 & $0.007 * *$ \\
\hline Soil temperature & 7.220 & $0.020 *$ & 0.606 & 0.451 & 1.588 & 0.232 \\
\hline Organic matter content & 1.532 & 0.240 & 19.650 & $0.001 * * *$ & 15.670 & $0.002 * *$ \\
\hline
\end{tabular}

Data were tested using ANOVA $(n=7)$, including site number as a random factor. Significant effects $(p<0.05)$ are marked in bold. Significance levels: *** $p<0.001$; $* * p 0.01 ;{ }^{*} p<0.05 ;{ }^{+} p .<0.1$.

2017). This suggests that the graminoid- and forbdominated state is indeed stable, while the reindeer pressure in the plots has decreased to levels that would never support such vegetation transition. Therefore, this confirms a strong historical contingency (Fukami 2015) of herbivores on tundra vegetation. We propose a number of ecosystem processes that have been altered with the vegetation shift and contribute to the maintenance of this plant community after the initial change caused by high reindeer concentrations. These include increased nutrient turnover rates, strong competition of fast growing HMG vegetation and current levels of herbivory, which will be discussed in more detail below.

For the interior parts of HMGs, the vegetation surveys support a stable vegetation state. The community composition in the HMGs was not only distinctly different from the surroundings, with a strong dominance of graminoids and forbs, but the dwarf shrubs and shrubs dominating the surroundings were still virtually absent after a century; not even seedlings of those species were found. In apparent contrast, the comparison of aerial photographs from 1964 and 2008 showed that almost all HMGs are slowly shrinking. Shrubs encroached into most HMGs along parts of the borders, although all HMGs also had parts where the border remained stable. Shrubs might invade HMGs either vegetatively or through seed dispersal. The virtual absence of shrubs in the inner parts of HMGs, according to both the aerial photographs and vegetation surveys of core areas, suggests that the main mechanism of shrub encroachment is through vegetative dispersal along the borders. Tundra shrub species like Betula nana are known to be favored by $\mathrm{N}$ fertilization (Bret-Harte and others 2001), and accordingly we found higher encroachment rates in the HMGs with more nutrient-rich soils. Given that the environmental conditions within HMGs are suitable for these shrub species, the average rate of encroachment that we observed $\left(0.05 \mathrm{~m} \mathrm{y}^{-1}\right)$ is still remarkably low in comparison with rapid shrubification reported from many parts of the arctic in response to a warmer climate (Myers-Smith and others 2011), which ranges up to shrub and tree expansion rates of $3 \mathrm{~m} \mathrm{y}^{-1}$ during recent decades (Rundqvist and others 2011; Callaghan and others 2013). Furthermore, the actual encroachment of the HMGs was even slower, since detailed ground truth vegetation inventories of areas classified as "invaded" in the aerial photographs, showed they were in fact intermediate between HMG and control vegetation.

There was also a strong historical contingency on the nutrient availability in the soil, although there were partly contrasting patterns between heath and shrub sites. Mineral nitrogen availability was higher and soil $\mathrm{C} / \mathrm{N}$ ratio lower in the HMGs in the nutrient-poor heath sites, and in line with our prediction, the increased mineral nitrogen availability was not associated with a larger total nitrogen stock, as has been found in some other places 

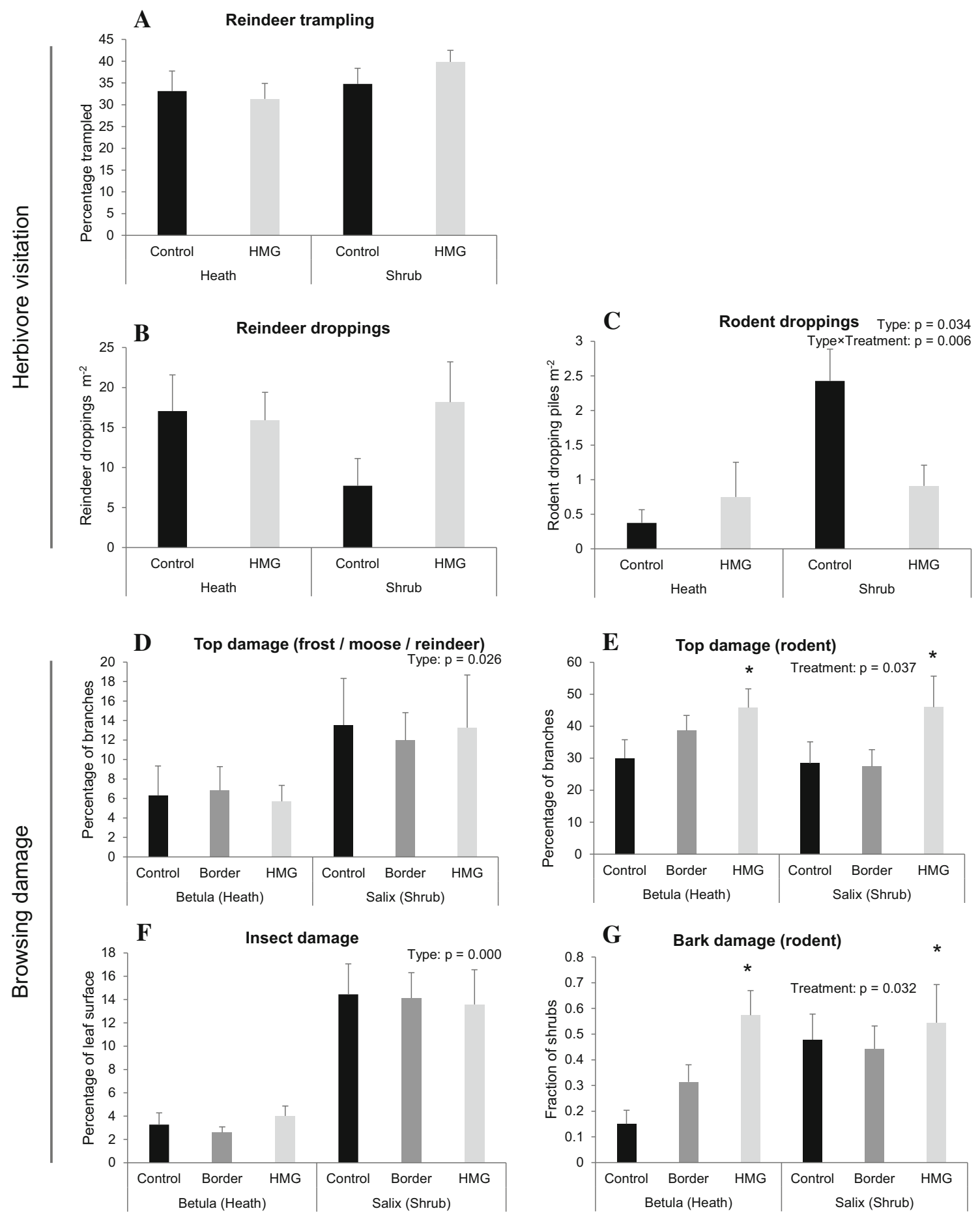

Figure 6. Herbivore visitation $(\mathbf{A}-\mathbf{C})$ measured as $\mathbf{A}$ reindeer trampling, $\mathbf{B}$ reindeer dung and $\mathbf{C}$ rodent dung per year in controls and HMGs in heath and shrub habitats, averaged over the years 2015 and 2016. Data shown are mean values + SE; $n=7$. *Indicates significant treatment effects of control versus HMG $(p<0.05)$. The $p$ values show significant outcomes of ANOVA including site vegetation type (heath or shrub) and treatment (control or HMG) as factors and using site number as an error factor. Browsing damage (D-G) on the dominant shrub species (Betula nana in heath and Salix spp. in shrub) was measured in controls, along stable borders and in HMGs in terms of $\mathbf{D}$ top damage caused by frost, moose or reindeer, $\mathbf{E}$ top damage caused by rodents, $\mathbf{F}$ insect damage on leaves and $\mathbf{G}$ bark damage caused by rodents. Data shown are mean values + SE. *Indicates significant treatment effects (control, border and HMG) $(p<0.05)$ and $p$ values of significant ANOVA outcomes including the factors type (heath or shrub) and treatment (control, border or HMG) are included. 
Table 3. Effects of Vegetation Type and Treatment on Herbivory

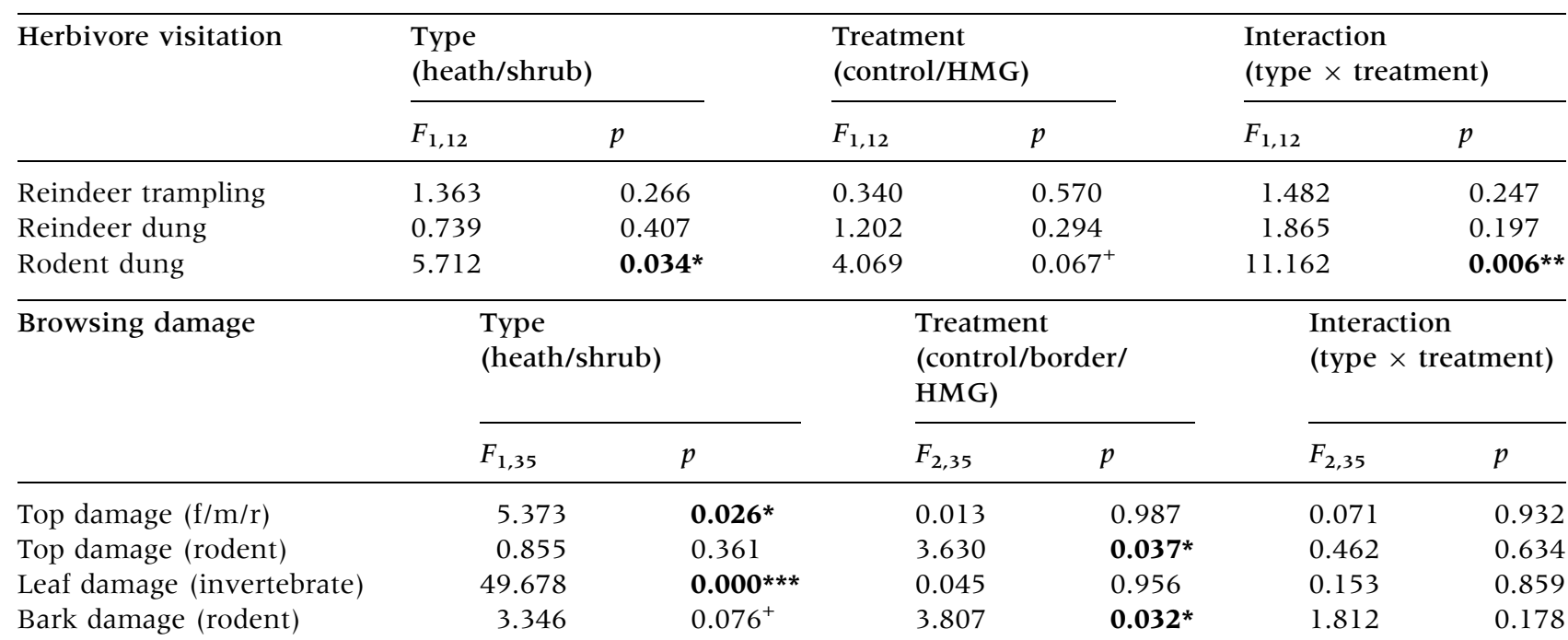

Herbivore visitation in control and HMG, and browsing damage on shrubs in controls, along stable borders and in HMG. Herbivore visitation data were tested using ANOVA $(n=7)$, including site number as a random factor. Browsing damage data were also tested using ANOVA $(n=7$ for all types except for heath-HMG, where $n=6)$. Significant effects $(p<0.05)$ are marked in bold. Significance levels: $* * *<0.001 ; * * p<0.01 ;{ }^{*} p<0.05 ;{ }^{+} p<0.1$.

where livestock was kept in the past in boreal forests (Freschet and others 2014) and savannas (Valls Fox and others 2015). The total N pool even tended to be smaller in the HMGs, although the difference was not statistically significant. The most likely explanation for the higher mineral nutrient availability is, thus, a higher nitrogen turnover rate due to higher litter and soil organic matter quality (Hobbie 1992; Chapin and others 1996) and increased soil microbial activity (Van der Putten and others 2013; Freschet and others 2014). This conclusion may be further supported by the lack of any difference in mineral $\mathrm{N}$ availability in the shrubtype vegetation, where, based on the plant community composition, the litter quality may be relatively similar between the HMG and control.

In contrast to expectations, mineral $\mathrm{P}$ was lower in both types of HMGs compared to their corresponding controls. This result was surprising as phosphorus is usually concentrated around human settlements in northern ecosystems (Linderholm 2007), and in African bomas (confined areas in savanna where livestock was kept overnight) (Valls Fox and others 2015). One possible explanation for the partly diverging patterns between mineral $\mathrm{N}$ and $\mathrm{P}$ is that the HMGs were historically mainly influenced by reindeer while the impact of the human settlement per se was fairly low. Contrasting with soil $\mathrm{N}$ cycling, reindeer grazing might not enhance soil $\mathrm{P}$ cycling as reindeer have a higher phosphorus demand than most other herbivores since both sexes have large antlers rich in phos- phorus (Moen and others 1999; Andersen and others 2004). They are therefore unlikely to recycle $\mathrm{P}$ as much as $\mathrm{N}$, resulting in a high plant demand of phosphorus and thus may decrease $\mathrm{P}$ availability in the soil (Sitters and others 2017). The deep-rooted shrubs in the control plots might also mobilize $\mathrm{P}$ (DeLuca and Zackrisson 2007) and thus keep P concentrations higher in control plots than in HMGs. It should be noted that we only measured a difference in mineral $\mathrm{P}$ and that total $\mathrm{P}$ concentrations might still be higher in HMGs (Linderholm 2007), even if the plant-available $P$ has decreased. Noteworthy, at least in the heath habitat, P concentrations were more than five times higher in controls than in HMGs, and the difference is thus not likely to be spurious.

Even though both the vegetation and soil properties in HMGs are distinctly different from their control plots, recordings from the period during which they were actively used are lacking and it is not possible to determine exactly how these properties have changed over the last century when milking grounds were no longer used. We can, however, approach this question by comparing the HMGs with sites that are heavily grazed today, such as areas close to reindeer herding fences (te Beest and others 2016; Sitters and others 2017). The vegetation in these heavily grazed sites is very similar to the vegetation in the HMGs with the exception of mosses that are rare in the presently heavily grazed sites (Olofsson and others 2001; Barthelemy 2016; te Beest and others 2016; Sitters 
and others 2017), but abundant in the HMGs. This difference is noteworthy because the extent of the moss layer can play an important role in arctic vegetation by regulating soil temperature and moisture (Gornall and others 2007).

Despite that the grazing pressure has been at least an order of magnitude lower than the active grazing that created the vegetation transition more than a century ago, changes in nitrogen availability HMG soils were comparable to actively heavily grazed areas with herbaceous vegetation. Similar to our study on HMGs, Sitters and others (2017) found that grazing increased mineral nutrient availability and decreased soil C:N ratio in nutrient-poor heath (exposed ridges and higher zonal sites), whereas there was no difference in response to grazing in the naturally more nutrient-rich shrub and meadow habitats (lower zonal sites) studied. This suggests that the major driver of increased mineral nutrient availability should be the same in both HMGs and actively grazed systems and thus points toward a high importance of positive feedbacks on nutrient cycling via higher litter quality, as suggested by Olofsson and Oksanen (2002). One major difference between HMGs and actively grazed sites is that in the latter, fertilization by urine and feces contributes to a higher $\mathrm{N}$ turnover rate, which may explain why we find slightly lower mineral $\mathrm{N}$ concentrations in HMG soils $\left(\sim 1.1 \mathrm{~g} \mathrm{~m}^{-2}\right)$ compared to the actively grazed sites $\left(\sim 1.7 \mathrm{~g} \mathrm{~m}^{-2}\right)$ (Sitters and others 2017). In arctic vegetation, $\mathrm{N}$ from droppings (Barthelemy and others 2015) and urine (Sjögersten and others 2010; Barthelemy and others 2018 ) is efficiently taken up by the vegetation but also contributes to higher $\mathrm{N}$ concentrations in soils, as evidenced by the contiguity of increasing nutrients with reindeer migration (Stark and Väisänen 2014). A possible additional factor contributing to increased $\mathrm{N}$ availability in HMGs is the higher abundance of feather mosses like Pleurozium schreberi and Hylocomium splendens (Appendix 4 in ESM), as they often grow in association with $\mathrm{N}_{2}$ fixing cyanobacteria, adding atmospheric $\mathrm{N}$ to the system (Lett and Michelsen 2014). However, how much $\mathrm{N}$ is actually fixed is not easily predictable based on the abundance of mosses alone, and they probably do not contribute to the high $\mathrm{N}$ availability in actively grazed sites where these mosses are less abundant (Olofsson and others 2004). The strong similarity between actively heavily grazed sites and HMGs, both in terms of vegetation composition and nutrient dynamics, suggests that the changes in the HMGs have been minor over the last century.
The slow reinvasion of shrubs into the abandoned HMGs, albeit under suitable abiotic conditions, indicates that biotic interactions may be important in limiting shrub establishment. We consider it unlikely that seed dispersal limitation would be an important factor here, since seedproducing shrubs grow in close proximity to all HMGs. It is well documented that competition from dense grass swards prevents woody seedling establishment in grasslands in general (Köchy and Wilson 2000), and also specifically in alpine grasslands (Welling and Laine 2002; Olofsson and Shams 2007; Klanderud 2010; Milbau and others 2013). Dense grass swards, aided by a high mineral $\mathrm{N}$ availability in the HMGs, probably efficiently prevent shrubs from establishing from seeds. Moreover, since competition from established plants is often stronger on small seedlings than on large established plants (Grace and Tilman 1990), the competition from established graminoids could have a stronger effect on seedlings in the interior of the HMGs than on large shrubs dispersing by vegetative growth at the edges and could thus explain why the borders were slowly invaded by vegetatively regrowing shrubs, while the interior remained free of shrubs.

Herbivores could further contribute to the resistance of the HMGs to invading shrubs. In some grazing ecosystems, heavily grazed patches are maintained because they attract large herbivores, which in turn reinforces a graminoid-dominated, grazing-tolerant vegetation (for example, grazing lawns, McNaughton 1984; Valls Fox and others 2015). However, visitation (trampling or droppings) or signs of grazing on plants by domesticated reindeer, the only common large herbivore, were not enhanced in HMGs compared to controls. The reindeer density in the area could still slow down the shrub encroachment, because the density of reindeer is within the same range as in areas where grazing has been found to slow down, but not fully prevent shrub encroachment (Olofsson 2009; Parsons 2016). In contrast, the frequency of signs of rodent damage was substantially higher on shrubs growing inside the HMGs than in control areas. The level of rodent damage on shrubs in the HMGs (almost $50 \%$ of the shoots being cut and more than $50 \%$ of shrubs having bark damage) was clearly high enough to reduce shrub encroachment into HMGs severely. Moreover, the recorded damage was mainly caused by a single rodent peak, and shrubs will have to survive multiple rodent peaks to establish in a new habitat. Although we did not directly analyze plant quality, it has been shown in previous studies that shrubs growing in herbaceous 
vegetation have a higher nitrogen concentration (Olofsson and Oksanen 2002; Sitters and others 2017), which could drive the high feeding rates of rodents on HMG shrubs. The importance of rodent herbivory in driving the stability of HMGs is supported by earlier findings that voles and other rodents can cause high mortality of shrubs in the arctic (Ravolainen and others 2014), reduce the abundance of dwarf shrubs even at landscape scales (Olofsson and others 2012), and prevent shrubs from increasing following warming (Kaarlejärvi and others 2015). Voles and lemmings also play a vital role in preserving natural arctic grasslands, by keeping snowbeds dominated by herbaceous vegetation and preventing mosses or dwarf shrubs from expanding (Virtanen and others 1997; Olofsson and others 2014). According to the pellet counts, small rodents (voles and lemmings) occurred at higher densities in the control plots than in the HMGs in the shrub habitat, probably because snow conditions were softer under the shrubs during winter and the rodents can find shelter under shrubs from predation during summer (Sokolova and others 2014).

The studied HMGs are strikingly stable, illustrated by differences in plant community composition and nutrient availability that have been preserved for at least a century since active use ceased. As our study design could only detect HMGs that still are present today, we cannot exclude a possibility that some HMGs had already disappeared during the first 50 years after their abandonment (that is, before the oldest aerial photographs were taken). This could lead to overestimating the general stability of HMGs during the last century. Considering the very slow rates at which the presently observable HMGs had been shrinking during the last 50 years, this seems relatively unlikely. In the HMGs, higher reindeer densities in the past (alteration in state variable) drove the initial vegetation change, and our results suggest that positive plant-soil feedbacks maintaining a high nutrient availability, intense competition from the dense grass sward, and herbivory from reindeer and rodents are changed parameters (environmental drivers) that contribute to maintaining the vegetation in this altered state, sensu Beisner and others (2003). This does raise the question of whether HMGs can be regarded as an alternative stable state. According to common definitions, a community can be considered stable when it is resistant to colonization although all species in the species pool have had multiple chances to colonize, and when it has undergone population dynamics over multiple generations within the community since initiation (Fukami 2015). The studied HMGs do fulfill the first of these criteria, since shrubs have not been able to establish from seeds, although numerous seeds of many different shrub species arrive in the HMGs every year. The second criterion is harder to evaluate since although individual tillers of perennial graminoids typically live for a few years up to a few decades (Callaghan 1980), the age of genetic individual clonal plants is hard to determine, but can potentially be centuries or even millennia (De Witte and Stöcklin 2010). Probably, the long life span of the plants increases the stability of the vegetation states (Eriksson 2000). However, if a century of resistance to being invaded is not sufficient to be categorized as an alternative stable state, the practical value of the concept will be limited in all terrestrial plant communities containing clonal plants. Therefore, a more relevant issue is whether these HMGs should be regarded as stable, or slowly changing, that is, alternative transient stages $(\mathrm{Fu}-$ kami 2015), since the nutrition status of the soils might be slowly changing and since shrubs are indeed vegetatively invading along the edges of the milking grounds. The answers to both these questions seem to relate to the temporal and spatial scale considered. The enhanced soil nutrient status is regarded as stable when observed after a century, but perhaps not at even longer timescales since a higher nutrient cycling rate is expected to be associated with higher nutrient losses in the long term (Mitton and Grant 1996). Moreover, given the slow rate of vegetative ingrowth, large patches of several hectares of herbaceous vegetation could be persistent for millennia, whereas patches of a few square meters will probably disappear in a few decades. However, no matter the definition, we conclude that historical milking grounds are at least very stable at ecological timescales and represent clear examples of strong historical contingency of herbivore effects in an arctic environment. Although the here studied vegetation transitions are caused by domesticated reindeer, similar vegetation shifts caused by wild arctic herbivores have also been reported (Thing 1984; Zimov and others 1995a; van der Wal and Brooker 2004; van der Wal 2006). Even if the frequency of such vegetation shifts are poorly known, it is still clear that the composition and function of arctic ecosystems today are thus shaped by herbivory impacts centuries ago and cannot easily be understood based on the present conditions alone. A major research question for the future is to understand under which conditions historical contingency is strong in ecosystems and more specifically under which 
conditions herbivore-driven vegetation changes are long-lasting.

\section{ACKNOWLEDGEMENTS}

We pay special thanks to the following people: Elin Lindén, Torun Bergman, Louise Berglund, Erik-Jan Bijleveld and Lauralotta Muurinen for amazing help with the field, Sirkka Aakkonen for helping with soil analyses and Mariska te Beest for many helpful discussions on the topic. Thoughtful comments from two anonymous reviewers greatly improved the manuscript. We thank Länsstyrelssen Norbotten for granting us the opportunity to work in Padjelanta National Park. This study was funded by a grant to Johan Olofsson from the Swedish Research Council Formas 2012-1039, 2012-230, 2015-1091.

\section{OPEN ACCESS}

This article is distributed under the terms of the Creative Commons Attribution 4.0 International License (http://creativecommons.org/licenses/by/ 4.0/), which permits unrestricted use, distribution, and reproduction in any medium, provided you give appropriate credit to the original author(s) and the source, provide a link to the Creative Commons license, and indicate if changes were made.

\section{REFERENCES}

Andersen O. 2017. Landskap og kulturminner i Gierggebuodo i Divtasvuona suokhan/Tysfjord kommune. Analyser av ulike typer kilder for å dokumentere bruken av området. In: Tjálarájddo - Árran julevsáme guovdasj - nr. 2. Gielas/Kjölen. pp 41-64.

Andersen T, Elser JJ, Hessen DO. 2004. Stoichiometry and population dynamics. Ecol Lett 7:884-900.

Aronsson K-Å. 1991. Forest reindeer herding A.D. 1-1800: an archaeological and palaeoecological study in northern Sweden. Department of Archaeology, Umeå University.

Aronsson K-Å. 2009. Recent perspectives on Sami archaeology in Fennoscandia and North-West Russia: Proceedings of the first international conference on Sami archaeology, Rovaniemi, 1922 Oct 2006. In: Halinen P, Lavento M, Suhonen M, editors. Relations between man and reindeer-traces of reindeer herding. Helsinki: Finnish Antiquarian Society. pp 17-24.

Aronsson K-Å, Israelsson I. 2008. Kunskapsuppbyggnad om fjällens natur- och kulturvärden särskilt det biologiska kulturarvet: Jokkmokk kommun, Gällivare kommun, Norrbottens län: arkeologisk dokumentation.

Bakker ES, Gill JL, Johnson CN, Vera FW, Sandom CJ, Asner GP, Svenning JC. 2016. Combining paleo-data and modern exclosure experiments to assess the impact of megafauna extinctions on woody vegetation. Proc Natl Acad Sci 1 13:847-55.

Bardgett RD, Wardle DA. 2003. Herbivore-mediated linkages between aboveground and belowground communities. Ecology 84:2258-68.
Barrio IC, Hik DS, Jónsdóttir IS, Bueno CG, Mörsdorf MA, Ravolainen VT. 2016. Herbivory network: an international, collaborative effort to study herbivory in Arctic and alpine ecosystems. Polar Sci 10:297-302.

Barrio IC, Lindén E, Te Beest M, Olofsson J, Rocha A, Soininen EM, Alatalo JM, Andersson T, Asmus A, Boike J, Bråthen KA, Bryant JP, Buchwal A, Bueno CG, Christie KS, Denisova YV, Egelkraut D, Ehrich D, Fishback L, Forbes BC, Gartzia M, Grogan P, Hallinger M, Heijmans MMPD, Hik DS, Hofgaard A, Holmgren M, Høye TT, Huebner DC, Jónsdóttir IS, Kaarlejärvi E, Kumpula T, Lange CYMJG, Lange J, Lévesque E, Limpens $\mathrm{J}$, Macias-Fauria M, Myers-Smith I, van Nieukerken EJ, Normand S, Post ES, Schmidt NM, Sitters J, Skoracka A, Sokolov A, Sokolova N, Speed JDM, Street LE, Sundqvist MK, Suominen O, Tananaev N, Tremblay J-P, Urbanowicz C, Uvarov SA, Watts D, Wilmking M, Wookey PA, Zimmermann HH, Zverev V, Kozlov MV. 2017. Background invertebrate herbivory on dwarf birch (Betula glandulosa-nana complex) increases with temperature and precipitation across the tundra biome. Polar Biol 40:2265-78.

Barthelemy H. 2016. Herbivores influence nutrient cycling and plant nutrient uptake: insights from tundra ecosystems. Umeå: Umeå University, Department of Ecology and Environmental Science.

Barthelemy H, Stark S, Olofsson J. 2015. Strong responses of subarctic plant communities to long-term reindeer feces manipulation. Ecosystems 18:740-51.

Barthelemy H, Stark S, Michelsen A, Olofsson J. 2018. Urine is an important nitrogen source for plants irrespective of vegetation composition in an Arctic tundra: insights from a enriched urea tracer experiment. J Ecol 106:367-78.

Beach H. 1981. Reindeer-herd management in transition: the case of Tuorpon Saameby in northern Sweden. Uppsala: Uppsala University.

Beisner BE, Haydon DT, Cuddington K. 2003. Alternative stable states in ecology. Front Ecol Environ 1:376-82.

Bergman I, Liedgren L, Östlund L, Zackrisson O. 2008. Kinship and settlements: Sami residence patterns in the Fennoscandian Alpine areas around A.D. 1000. Arctic Anthropol 45:97110 .

Bremner JM. 1965. Inorganic forms of nitrogen. In: Black CA, Ed. Methods of soil analysis, part 2. Madison: American Society of Agronomy. p 1179-237.

Bret-Harte SM, Shaver GR, Zoerner JP, Johnstone JF, Wagner JL, Chavez AS, Gunkelman RFIV, Lippert SC, Laundre JA. 2001. Developmental plasticity allows betula nana to dominate tundra subjected to an altered environment. Ecology $82: 18-32$

Brookes PC, Landman A, Pruden G, Jenkinson DS. 1985. Chloroform fumigation and the release of soil nitrogen: a rapid direct extraction method to measure microbial biomass nitrogen in soil. Soil Biol Biochem 17:837-42.

Callaghan TV. 1980. Age-related patterns of nutrient allocation in Lycopodium annotinum from Swedish Lapland: strategies of growth and population dynamics of Tundra Plants 5. Oikos $35: 373-86$

Callaghan TV, Jonasson C, Thierfelder T, Yang Z, Hedenås H, Johansson M, Molau U, Van Bogaert R, Michelsen A, Olofsson J, Gwynn-Jones D, Bokhorst S, Phoenix G, Bjerke JW, Tømmervik H, Christensen TR, Hanna E, Koller EK, Sloan VL. 2013. Ecosystem change and stability over multiple decades in the Swedish subarctic: complex processes and multiple dri- 
vers. Philos Trans R Soc B Biol Sci. https://doi.org/10.1098/ rstb.2012.0488.

Chapin FS, BretHarte MS, Hobbie SE, Zhong HL. 1996. Plant functional types as predictors of transient responses of arctic vegetation to global change. J Veg Sci 7:347-58.

Chase JM. 2003. Community assembly: when should history matter? Oecologia 136:489-98.

DeLuca TH, Zackrisson O. 2007. Enhanced soil fertility under Juniperus communis in arctic ecosystems. Plant Soil 294:14755.

De Witte LC, Stöcklin J. 2010. Longevity of clonal plants: Why it matters and how to measure it. Ann Bot 106:859-70.

Eriksson O. 2000. Functional roles of remnant plant populations in communities and ecosystems. Glob Ecol Biogeogr 9:443-9.

Forbes BC. 2006. Reindeer management in northernmost Europe: linking practical and scientific knowledge in social-ecological systems. (Forbes BC, editor.). Berlin: Springer

Forbes BC, Stammler F, Kumpula T, Meschtyb N, Pajunen A, Kaarlejärvi E. 2009. High resilience in the Yamal-Nenets social-ecological system, West Siberian Arctic, Russia. Proc Natl Acad Sci 106:22041-8.

Freschet GT, Östlund L, Kichenin E, Wardle DA, Ostlund L, Kichenin E, Wardle DA. 2014. Aboveground and belowground legacies of native Sami land use on boreal forest in northern Sweden 100 years after abandonment. Ecology 95:963-77.

Fukami T. 2015. Historical contingency in community assembly: integrating niches, species pools, and priority effects. Annu Rev Ecol Evol Syst 46:1-23.

Gornall JL, Jónsdóttir IS, Woodin SJ, Wal R. 2007. Arctic mosses govern below-ground environment and ecosystem processes. Oecologia 153:931-41.

Grace JB, Tilman D. 1990. Perspectives on plant competition. (Grace JB, Tilman D, editors.). San Diego, California: Academic Press, Inc.

Hirota M, Holmgren M, van Nes EH, Scheffer M. 2011. Global resilience of tropical forest. Science 334:232-5.

Hobbie SE. 1992. Effects of plant species on nutrient cycling. Trends Ecol Evol 7:336-9.

Jones DL, Shannon D, Murphy DV, Farrar J. 2004. Role of dissolved organic nitrogen (DON) in soil $\mathrm{N}$ cycling in grassland soils. Soil Biol Biochem 36:749-56.

Kaarlejärvi E, Hoset KS, Olofsson J. 2015. Mammalian herbivores confer resilience of Arctic shrub-dominated ecosystems to changing climate. Glob Change Biol 21:3379-88.

Kardol P, Cornips NJ, Van Kempen MML, Bakx-Schotman JMT, Van Der Putten WH. 2007. Microbe-mediated plant-soil feedback causes historical contingency effects in plant community assembly. Ecol Monogr 77:147-62.

Karlsson H. 2008. Vegetation Changes and Forest-Line Positions in the Swedish Scandes during Late Holocene. Umeå: Swedish University of Agricultural Sciences, Department of Forest Ecology and Management.

Klanderud K. 2010. Species recruitment in alpine plant communities: the role of species interactions and productivity. $\mathrm{J}$ Ecol 98:1128-33.

Köchy M, Wilson SD. 2000. Competitive effects of shrubs and grasses in prairie. Oikos 91:385-95.

Law R. 1999. Theoretical aspects of community assembly. In: McGlade J, Ed. Advanced ecological theory: principles and applications. Oxford: Blackwell Oxford. p 143-71.
Lett S, Michelsen A. 2014. Seasonal variation in nitrogen fixation and effects of climate change in a subarctic heath. Plant Soil 379:193-204.

Linderholm J. 2007. Soil chemical surveying: a path to a deeper understanding of prehistoric sites and societies in Sweden. Anthropocene 22:417-38.

Lundmark L. 2007. Reindeer pastoralism in Sweden 1550-1950. Rangifer 27:9-16.

Manker E. 1947. De svenska fjällapparna. Stockholm: Stockholm: Svensk turistföreningen förlag

Manseau M, Huot J, Crete M. 1996. Effects of summer grazing by caribou on composition and productivity of vegetation: community and landscape level. J Ecol 84:503-13.

McNaughton SJ. 1984. Grazing lawns-animals in herds, plant form, and coevolution. Am Nat 124:863-86.

Milbau A, Shevtsova A, Osler N, Mooshammer M, Graae BJ. 2013. Plant community type and small-scale disturbances, but not altitude, influence the invasibility in subarctic ecosystems. New Phytol 197:1002-11.

Milchunas DG, Lauenroth WK. 1993. Quantitative effects of grazing on vegetation and soils over a global range of environments. Ecol Monogr 63:327-66.

Milchunas DG, Sala OE, Lauenroth WK. 1988. A generalized model of the effects of grazing by large herbivores on grassland community structure. Am Nat 132:87-106.

Mitton JB, Grant MC. 1996. Genetic variation and the natural history of quaking aspen. Bioscience 46:25-31.

Moen RA, Pastor J, Cohen Y. 1999. Antler growth and extinction risk of Irish elk. Evol Ecol Res 1:235-49.

Myers-Smith IH, Forbes BC, Wilmking $M$, Hallinger M, Lantz T, Blok D, Tape KD, Macias-Fauria M, Sass-Klaassen U, Lévesque E, Boudreau S, Ropars P, Hermanutz L, Trant A, Collier LS, Weijers S, Rozema J, Rayback SA, Schmidt NM, SchaepmanStrub G, Wipf S, Rixen C, Ménard CB, Venn S, Goetz S, Andreu-Hayles L, Elmendorf S, Ravolainen V, Welker J, Grogan P, Epstein HE, Hik DS. 2011. Shrub expansion in tundra ecosystems: dynamics, impacts and research priorities. Environ Res Lett 6:45509.

Noy-Meir I. 1975. Stability of grazing systems: an application of predator-prey graphs. J Ecol 63:459-81.

Oksanen J, Blanchet FG, Kindt R, Legendre P, Minchin PR, O'Hara RB, Simpson GL, Solymos P, Henry M, Stevens H, Wagner H. 2015. Vegan: community ecology package. http:// cran.r-project.org/package=vegan. Accessed 15 Oct 2016

Olaus M. 1555. Historia om de nordiska folken. [Ny utg.]. Hedemora: Gidlund

Olofsson J. 2006. Short- and long-term effects of changes in reindeer grazing pressure on tundra heath vegetation. J Ecol 94:431-40.

Olofsson J. 2009. Effects of simulated reindeer grazing, trampling, and waste products on nitrogen mineralization and primary production. Arctic Antarct Alp Res 41:330-8.

Olofsson J, Oksanen L. 2002. Role of litter decomposition for the increased primary production in areas heavily grazed by reindeer: a litterbag experiment. Oikos 96:507-15.

Olofsson J, Shams H. 2007. Determinants of plant species richness in an alpine meadow. J Ecol 95:916-25.

Olofsson J, Kitti H, Rautiainen P, Stark S, Oksanen L. 2001. Effects of summer grazing by reindeer on composition of vegetation, productivity and nitrogen cycling. Ecography (Cop) 24:13-24. 
Olofsson J, Stark S, Oksanen L. 2004. Reindeer influence on ecosystem processes in the tundra. Oikos 105:386-96.

Olofsson J, Tømmervik H, Callaghan TV. 2012. Vole and lemming activity observed from space. Nat Clim Chang 2:880-3.

Olofsson J, Oksanen L, Oksanen T, Tuomi M, Hoset KS, Virtanen R, Kyrö K. 2014. Long-term experiments reveal strong interactions between lemmings and plants in the fennoscandian highland tundra. Ecosystems 17:606-15.

Parsons M. 2016. Herbivore pressure of reindeer, rodents and invertebrates in the Fennoscandian tundra: a comparison of three methods. http://umu.diva-portal.org/smash/record. jsf?pid=diva2\%3A9728218dswid=1630. Accessed 1 June 2017.

R Core Team. 2013. R: a language and environment for statistical computing. http://www.r-project.org/. Accessed 1 Feb 2014.

Ravolainen VT, Bråthen KA, Yoccoz NG, Nguyen JK, Ims RA. 2014. Complementary impacts of small rodents and semidomesticated ungulates limit tall shrub expansion in the tundra. J Appl Ecol 51:234-41.

Rietkerk M, van de Koppel J. 1997. Alternative stable states and threshold effects in semi-arid grazing systems. Oikos 79:6976.

Ripple WJ, Beschta RL. 2012. Trophic cascades in Yellowstone: the first 15 years after wolf reintroduction. Biol Conserv 145:205-13.

Rundqvist S, Hedenås H, Sandström A, Emanuelsson U, Eriksson H, Jonasson C, Callaghan TV. 2011. Tree and shrub expansion over the past 34 years at the tree-line near Abisko, Sweden. Ambio 40:683-92.

Ruong I. 1982. Samerna i historien och nutiden. 4th edn. Stockholm: Bonnier fakta.

Sametinget. 2016. Sametinget. https://www.sametinget.se/ statistik_rennaring. Accessed 20 Nov 2016

Sitters J, te Beest M, Cherif M, Giesler R, Olofsson J. 2017. Interactive effects between reindeer and habitat fertility drive soil nutrient availabilities in arctic tundra. Ecosystems 20:1266-77.

Sjögersten S, Kuijper DPJ, van der Wal R, Loonen MJJE, Huiskes AHL, Woodin SJ. 2010. Nitrogen transfer between herbivores and their forage species. Polar Biol 33:1195-203.

Slatkin M. 1974. Competition and regional coexistence. Ecology 55:128-34.

SMHI. 2016. SMHI, Swedish Meteorological and Hydrological Institue. www.smhi.se. Accessed 16 Nov 2016.

Sokolova NA, Sokolov AA, Ims RA, Skogstad G, Lecomte N, Sokolov VA, Yoccoz NG, Ehrich D. 2014. Small rodents in the shrub tundra of Yamal (Russia): density dependence in habitat use? Mamm Biol 79:306-12.

Staland H, Salmonsson J, Hörnberg G. 2011. A thousand years of human impact in the northern Scandinavian mountain range: long-lasting effects on forest lines and vegetation. Holocene 21:379-91.

Stark S, Väisänen M. 2014. Insensitivity of soil microbial activity to temporal variation in soil $\mathrm{N}$ in Subarctic Tundra: evidence from responses to large migratory grazers. Ecosystems 17:90617.

Staver AC, Archibald S, Levin S. 2011. The global extent and determinants of savanna and forest as alternative biome states. Science 334:230-2.

te Beest M, Sitters J, Ménard CB, Olofsson J. 2016. Reindeer grazing increases summer albedo by reducing shrub abundance in Arctic tundra. Environ Res Lett 11:125013.
Thing H. 1984. Feeding ecology of the West Greenland caribou (Rangifer tarandus groenlandicus) in the Sisimiut-Kangerlussuaq region. Danish Rev Game Biol 12.

Tømmervik H, Dunfjeld S, Olsson GA, Nilsen MØ. 2010. Detection of ancient reindeer pens, cultural remains and anthropogenic influenced vegetation in Byrkije (Børgefjell) mountains, Fennoscandia. Landsc Urban Plan 98:56-71.

Uboni A, Horstkotte T, Kaarlejärvi E, Sévêque A, Stammler F, Olofsson J, Forbes BC, Moen J. 2016. Long-term trends and role of climate in the population dynamics of Eurasian reindeer. PLOS ONE 11:1-20.

Valls Fox H, Bonnet O, Cromsigt JPGM, Fritz H, Shrader AM. 2015. Legacy effects of different land-use histories interact with current grazing patterns to determine grazing lawn soil properties. Ecosystems 18:720-33.

Virtanen R, Henttonen H, Laine K. 1997. Lemming grazing and structure of a snowbed plant community-a long-term experiment at Kilpisjarvi, Finnish Lapland. Oikos 79:155-66.

van de Koppel J, Rietkerk M, Weissing FJ. 1997. Catastrophic vegetation shifts and soil degradation in terrestrial grazing systems. Trends Ecol Evol 12:352-6.

Van der Putten WH, Bardgett RD, Bever JD, Bezemer TM, Casper BB, Fukami T, Kardol P, Klironomos JN, Kulmatiski A Schweitzer JA, Suding KN, Van de Voorde TFJ, Wardle DA. 2013. Plant-soil feedbacks: the past, the present and future challenges. J Ecol 101:265-76.

van der Wal R. 2006. Do herbivores cause habitat degradation or vegetation state transition? Evidence from the tundra. Oikos 114:177-86.

van der Wal R, Brooker RW. 2004. Mosses mediate grazer impacts on grass abundance in arctic ecosystems. Funct Ecol 18:77-86.

von Düben G. 1873. Om Lappland och lapparne, företrädesvis de svenske: ethnografiska studier. Stockholm: Norstedt.

von Linné C. 1732. Iter Lapponicum: Lappländska resan 1732. (Fries S, Jacobsson R, editors.). Umeå: Kungl. skytteanska samfundet.

Wallin J-E, Aronsson K-̊. 2012. Vegetationsförändringar i Härjedalens och Jämtlands fjälltrakter under vikingatid och medeltid. In: Hemmendorff $\mathrm{O}$, editor. Människor i vikingatidens Mittnorden: föredrag vid de Mittnordiska arkeologidagarna i Östersund 2010. Fornvårdar. pp 180-208.

Welling P, Laine K. 2002. Regeneration by seeds in alpine meadow and heath vegetation in sub-arctic Finland. J Veg Sci 13:217-26.

Williams BL, Shand CA, Hill M, O'Hara C, Smith S, Young ME. 1995. A procedure for the simultaneous oxidation of total soluble nitrogen and phosphorus in extracts of fresh and fumigated soils and litters. Commun Soil Sci Plant Anal 26:91106.

Zimov SA, Chuprynin VI, Oreshko AP, Chapin FS, Chapin MC, Reynolds JF. 1995a. Effects of mammals on ecosystem change at the pleistocene-holocene boundary. Arct Alp Biodivers Patterns Causes Ecosyst Conseq 113:127-35.

Zimov SA, Chuprynin VI, Oreshko AP, Chapin FS, Reynolds JF, Chapin MC. 1995b. Steppe-tundra transition-a herbivoredriven biome shift at the end of the pleistocene. Am Nat 146:765-94. 